\title{
Sensitivity to selected contaminants in a biological early warning system using Anodonta woodiana (Mollusca)
}

\author{
Luisa Giari'*, Fabio Vincenzi', Elisa Anna Fano', Ivano Graldi' ${ }^{2}$, Fernando Gelli ${ }^{3}$ and Giuseppe Castaldelli' \\ ${ }^{1}$ Department of Life Sciences and Biotechnology, University of Ferrara, Borsari St. 46, 44121 Ferrara, Italy \\ ${ }^{2}$ ATO Ferrara, Ercole d'Este St. 14, 44121 Ferrara, Italy \\ ${ }^{3}$ ARPA Ferrara, Bologna St. 534, 44124 Ferrara, Italy
}

\begin{abstract}
Several early warning systems for the monitoring of water quality are based on the assessment of valve opening/closing in bivalves. Tests were conducted to assess the sensitivity of the mussel Anodonta woodiana, installed on the Mosselmonitor, to seven contaminants and evaluate the usefulness of these sensors for detecting pollution events in the Po River (Italy). Mussels were exposed for $30 \mathrm{~min}$ to increasing concentrations of chromium (range 0.01-5 mg/L); arsenic (range 0.05-2.5 $\mathrm{mg} / \mathrm{L}$ ); sodium dodecyl sulphate SDS (range $0.25-50 \mathrm{mg} / \mathrm{L}$ ); phenol (range $0.1-100 \mathrm{mg} / \mathrm{L}$ ); oxadiazon (range $0.001-5 \mathrm{mg} / \mathrm{L}$ ); trichloroethylene (range $0.01-100 \mathrm{mg} / \mathrm{L}$ ); and crude oil (range $0.5-50 \mathrm{mg} / \mathrm{L}$ ). Treatment with the highest concentration of SDS elicited two types of alarm response. In a second set of tests, the bivalves were exposed for $6 \mathrm{~h}$ to a selected concentration of each chemical. Only SDS led to a dramatic alteration of valve opening, resulting in alarms. This system would have limited applications for monitoring drinking water influent.
\end{abstract}

Keywords: bioindication, mussels, valve movement, toxicity test, toxic substances

\section{INTRODUCTION}

Monitoring the water quality of rivers that serve as public water supplies is a crucial and difficult task because contaminants from industrial and urban sources can be accidentally discharged at unpredictable times (White et al., 2002). Since the 1990s, in addition to the traditional chemical and physical methods, biological early warning systems (BEWS) have been increasingly applied for continuous surveillance of water (Kramer and Botterweg, 1991; Borcherding, 2006; Bae and Park, 2014). There is no universal system to monitor water quality and detect eventual contamination; indeed each monitor system should be assessed in the context of a specific water management body (Storey et al., 2011).

The US Environmental Protection Agency has evaluated the effectiveness of several sensors like Daphnia Toximeter, Algae Toximeter, Clam Monitor and fish monitors; however, very few biomonitors are used by public water utilities in the Unites States compared to Europe and Asia (White et al., 2002; Bae and Park, 2014). Many biomonitors have been implemented in Europe, especially in Germany on the Rivers Rhine, Elbe and Danube (White et al., 2002; Bae and Park, 2014). In view of the high risk of chemical discharges and the recent oil spill that occurred in the Po (Giari et al., 2012), the most important and impacted Italian river, the use of a BEWS was undertaken in the drinking water plant of the city of Ferrara (north-eastern Italy).

Thanks to their sedentary habit, manageable size, widespread distribution, and relative tolerance to xenobiotics, bivalve mussels are well suited as sentinels and are widely used for biomonitoring the aquatic environment (Englund and Heino, 1996; Kwan et al., 2003; Waykar and Shinde, 2011; Salahshur et al., 2012). The BEWS utilizing mussels is based on valvometry and relies on the tendency of bivalves to alter shell movements in response to toxicants and

*To whom all correspondence should be addressed.

Tel: +39(0) 532 455707; Fax +39(0)532455715 e-mail: grilsu@unife.it

Received 9 September 2015; accepted in revised form 6 March 2017 other stressful stimuli (Mosselmonitor, 2005). When mussels sense a foreign substance they may close the valves to reduce exposure, reduce the size of the valve opening, or increase activity by opening and closing more frequently than normal. When the shell remains at maximum open position for an extended time, this usually indicates death of the mussel (Mosselmonitor, 2005).

We believe that one of the main reasons for the current limited applications of BEWS employing mussels, is the difficulty to select the appropriate biosensor for specific site and conditions of use. A suitable bivalve to act as sentinel is a species that normally occur in the study area and for which stress responses (i.e. death) have already been reported. In our case, both Dreissena polymorpha and Anodonta woodiana were appropriate for installation on the mussel monitor, but only for the latter have die-offs been observed in the study area during the past decade (Castaldelli pers. observation).

As emphasised by Slooff et al. (1983) and Englund and Heino (1996), the assessment of detection thresholds indicated by valve movement patterns is crucial when estimating the efficacy of an early warning system and varies according to xenobiotic substance and mussel species. Potentially, several species of mussels, including Anodonta spp., can be utilized in BEWS; however, most available data has focused on the zebra mussel, D. polymorpha, in freshwater systems and blue mussel, Mytilus edulis, in marine waters (De Zwart et al., 1995; Borcherding and Jantz, 1997; Borcherding, 2006). For these species installed on the Mosselmonitor the detection limits (i.e. the lowest chemical concentrations leading to an alarm signal) have been reported for a limited number of chemicals (De Zwart et al., 1995; Mosselmonitor, 2005).

The major aims of this study were (i) to evaluate the sensitivity for selected chemicals under semi-field conditions of this biomonitoring system with Anodonta woodiana, a widespread species in lowland impacted rivers not previously used for this purpose, and (ii) based on the results obtained, to discuss the eventual usefulness of this system and how it can be improved for detecting contamination of drinking water influent. 


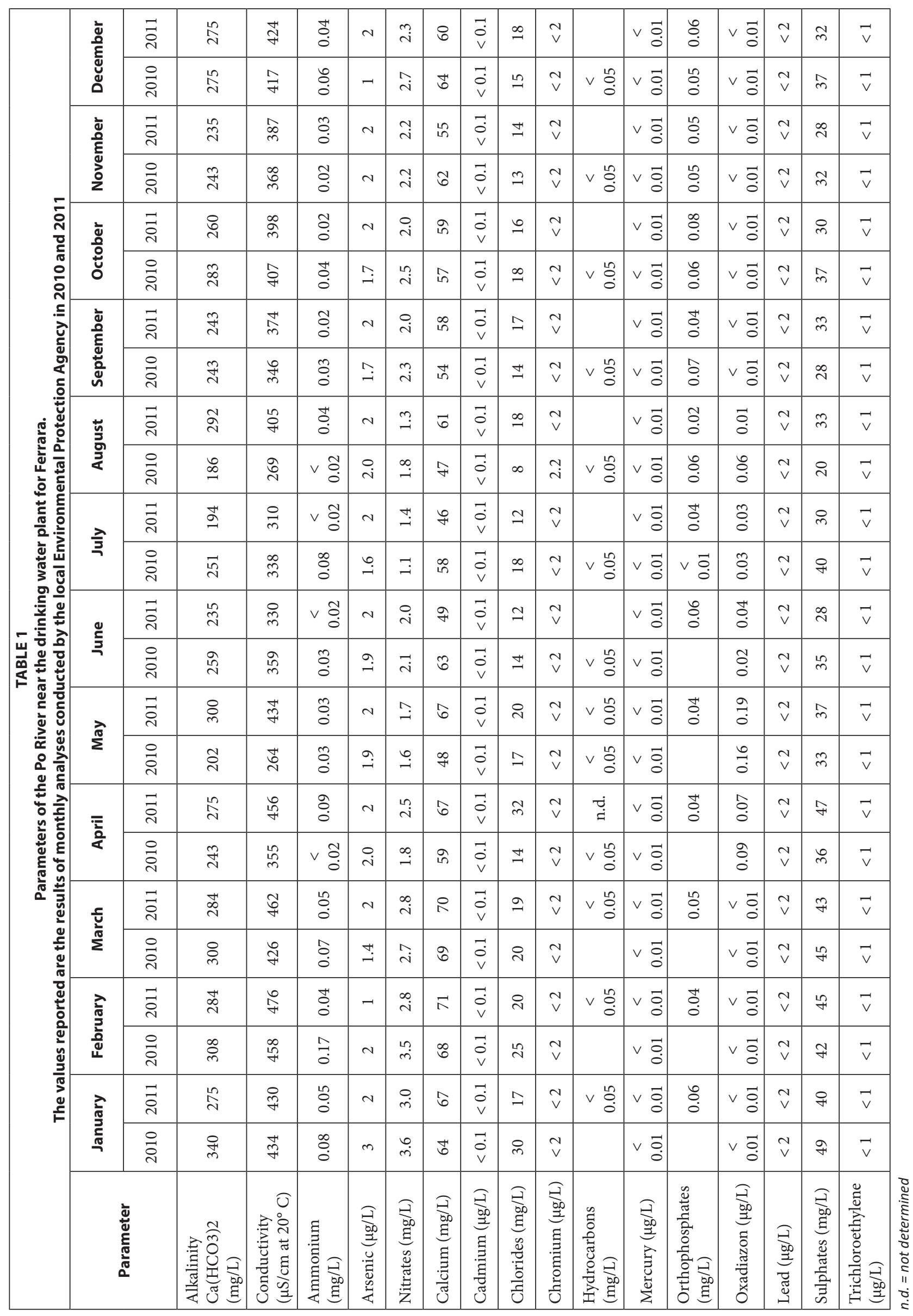




\section{METHODS}

\section{Biosensors}

Anodonta (Sinanodonta) woodiana (Lea, 1834) (Bivalvia, Unionidae) was used as test organism. This freshwater species originated from Eastern Asia (Watters, 1997) and is now widely distributed in several European countries, including Italy, where its occurrence was first recorded in the 1990s (Lodde et al., 2005). Fabbri and Landi (1999) stated that the native unionid Anodonta anatina had been completely replaced by $A$. woodiana in many Italian rivers that have a soft substrate and high trophic level. In the Po at the stretch in Ferrara city A. woodiana is the only bivalve species with suitable features to be used in a BEWS.

Sixteen specimens of $A$. woodiana (total length, the maximum antero-posterior dimension of the shell, 83-100 mm; $91.5 \pm 5.9 \mathrm{~mm}$, mean \pm standard deviation) were obtained from a local supplier. Eight mussels were used for the first series of tests and the remaining for the second battery of experiments. After their installation in the monitoring system, the bivalves were acclimated to Po River water for at least 3 weeks prior to experimentation. From July 2011 to January 2012, during both acclimatisation and trials, the mussels were subject to a natural photoperiod and fed on particulates naturally present in the water.

\section{Study area}

The BEWS was located in a biomonitoring station, a prefabricated cabin, within the drinking water plant of the city of Ferrara, Italy. This is the drinking water supply for about 250000 people and obtains water directly from the Po River, $80 \mathrm{~km}$ from its mouth in the Adriatic Sea. The Po is the longest and most important Italian river, originating in the Alps and flowing from west to east for $653 \mathrm{~km}$ across northern Italy to the Adriatic. After intake from the river, the untreated water flows into two circular primary sedimentation tanks, for the removal of sand and coarse particulates, and then into six artificial storage basins. Inside the biomonitoring station, the BEWS was placed in a polypropylene tank of approximately $60 \mathrm{~L}$ capacity containing flowing Po water (Table 1) before it entered the storage basins, thus at the beginning of the potabilisation process. The biomonitoring station was accessed only by the trained personnel involved in the use and maintenance of this BEWS, so the disturbance from human activity was reduced to the minimum.

\section{Mosselmonitor}

The monitoring system used in this survey is the in-situ version of the Mosselmonitor (Delta Consult B.V., The Netherlands). This instrument consists of a watertight polythene case containing the electronics necessary for measurements, data evaluation, and communication. On top of the instrument, 8 (the maximum number of mussels which can be used in this Mosselmonitor version) A. woodiana were held in place by fixing one valve to a PVC backplate with the second valve freely moving (Fig. 1). A sensor is fastened to the backplate and a second one to the free valve and inductive distance measurement at $250 \mathrm{kHz}$ between the sensors enables accurate calculating of the distance between the valves (Fig. 1).

Since the absolute values will vary according to size differences of the mussels and adjustment differences in the

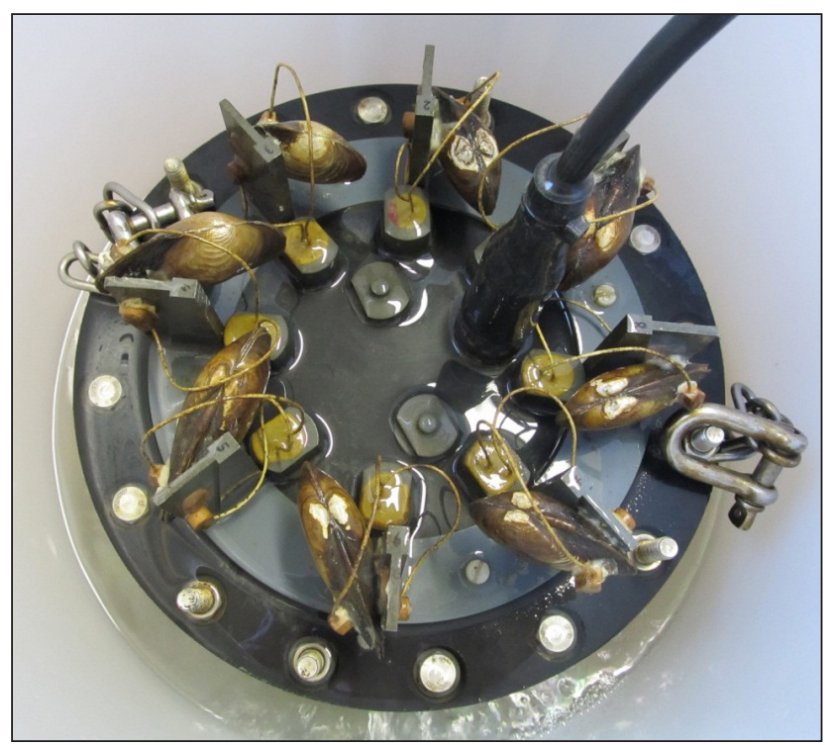

Figure 1

Top view of the Mosselmonitor used in this study. Each of the eight specimens of Anodonta woodiana had one valve fixed to a PVC backplate, equipped with a sensor, and the other valve freely moving with a second sensor. The height of the induced signal between the sensors enables calculation of the distance between the valves (i.e. shell opening).

electronics, the data are normalized and expressed as percentage of maximal span, with fully closed set at $0 \%$ and fully open at $100 \%$ (Fig. 2). The shell movement of each mussel is sequentially recorded and interpreted by a computer system comparing the results with previously recorded data for the same individual (Fig. 2). Deviation from normal movement patterns can include a decrease in average opening distance (Alarm D), prolonged closure (Alarm $\mathrm{C}$ ), increase in the valve movement frequency (Alarm A), and excessive opening due to death of the mussel (Alarm $\mathrm{G}$ ); these alarm signals can be viewed on the computer monitor (Fig. 2). A detailed description of the technical features and functioning of the Mosselmonitor is provided in Kramer and Foekema (2001).

Based on preliminary observations of $A$. woodiana behaviour, criteria were established for indicating the generation of the different types of alarms in order to reach a proper balance between sensitivity and reliability of the instrument in this specific environment (Po River water intake for public water supplies). The change of temperature and season between the first series of experiments, in the late summer, and the second, conducted during the winter, was taken into account and the threshold to trigger Alarm $\mathrm{C}$ was adjusted as suggested by Borcherding (2006). Differences in water temperature are reflected in the physiology of these ectothermic animals, with activity expected to decrease in winter (De Zwart et al., 1995).

The settings of the alarm thresholds used during the toxicity tests were:

- Alarm C: 4 (in the first series of tests) or 5 (in the second series of tests) of 8 mussels closed (valve position $<30 \%$ ) for 5 consecutive minutes; accordingly an alarm is generated when 4 or 5 mussels have and maintain a value of valve opening between 1 and 29\% (the system considers them 'closed' although they are not entirely closed) for at least 5 consecutive minutes. The 'closed' evaluation detects whether a relatively high number 
TABLE 2

List of the xenobiotics used for the toxicity test with Anodonta woodiana Mosselmonitor. For each xenobiotic the chemical features (formula, chemical class and producer) and the maximum allowable concentration in water for potabilisation process based on Italian standards are reported.

\begin{tabular}{|l|l|l|l|c|}
\hline Xenobiotic & Formula & Chemical class & Producer & $\begin{array}{c}\text { Permitted concentration (mg/L) in water to be treated } \\
\text { for human consumption based on Italian standards* }\end{array}$ \\
\hline Arsenic $(\mathrm{As})$ & As & metals & Fluka & 0.1 \\
\hline Chrome $(\mathrm{Cr})$ & $\mathrm{Cr}\left(\mathrm{NO}_{3}\right)_{3} 9 \mathrm{H}_{2} \mathrm{O}$ & metals & Riedel de haen & 0.05 \\
\hline Crude oil & $\mathrm{C} 9 / \mathrm{C}_{2} 0$ & hydrocarbons & Ip & 1 \\
\hline Oxadiazon & $\mathrm{C}_{15} \mathrm{H}_{18} \mathrm{Cl}_{2} \mathrm{~N}_{2} \mathrm{O}_{3}$ & pesticides & Bayer & 0.005 \\
\hline Phenol & $\mathrm{C}_{6} \mathrm{H}_{6} \mathrm{O}$ & phenols & Fluka & 0.1 \\
\hline $\begin{array}{l}\text { Sodium dodecyl } \\
\text { sulphate (SDS) }\end{array}$ & $\mathrm{C}_{12} \mathrm{H}_{25} \mathrm{O}_{4} \mathrm{SNa}$ & Surfactants & Duchefa & 0.5 \\
\hline Trichloroethylene & $\mathrm{C}_{2} \mathrm{HCl}_{3}$ & halogenated solvents & Sigma-Aldrich & 0.01 \\
\hline
\end{tabular}

${ }^{*}$ Laws no. 152 of 3 April 2006 and no. 31 of 2 February 2001

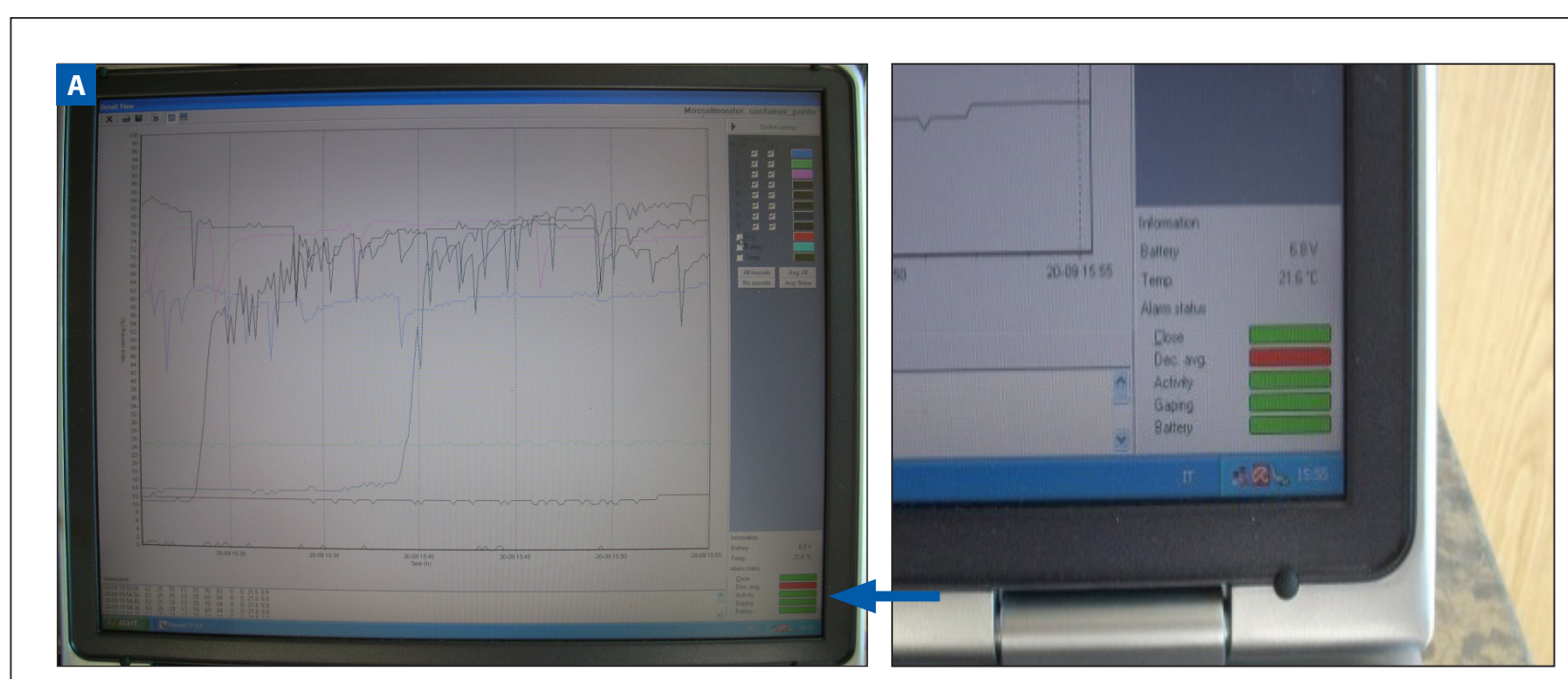

B Valve movements of the mussels during $30 \mathrm{~min}$ exposure to $\mathrm{Cr} 5 \mathrm{mg} / \mathrm{L}$

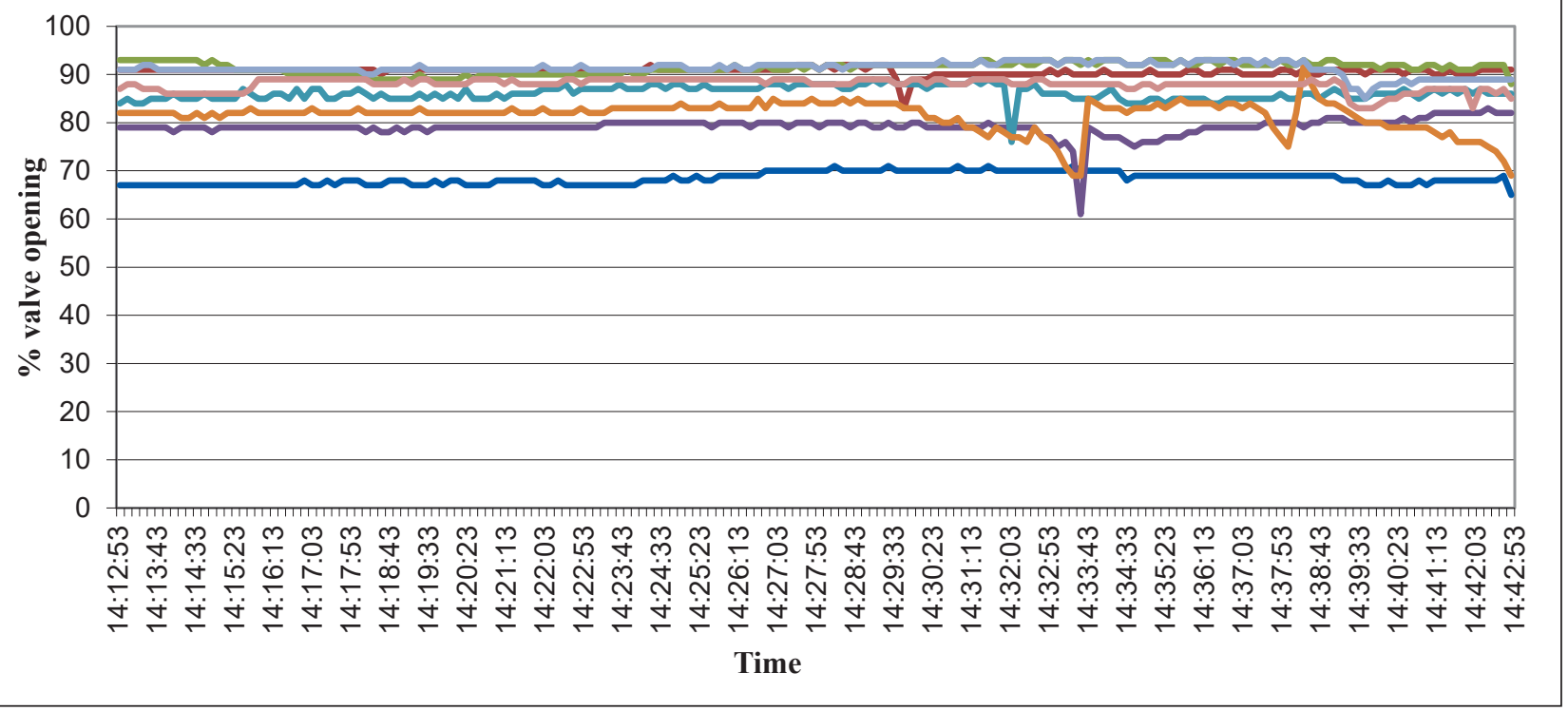

Figure 2

Examples of data collected from the Mosselmonitor and transmitted to the computer system. (a) picture of the computer monitor during the data collection (b) a graph generated with the data collected during an exposure test with chromium ( $\mathrm{Cr}$ ). In the graphs the shell position of each mussel is reported as percentage of valve opening (minimum or fully closed is set at $0 \%$ and maximum at 100\%) on the y-axis and the time on the $x$-axis. The shell movement of each mussel is compared by the software with previously recorded data of the same individual and based on the defined criteria an alarm signal (arrow) can be generated. 
of mussels remain closed for an unusually long time. The shorter the minimum 'closed' time and the smaller the number of mussels 'closed', the more sensitive is the system.

- Alarm D: 4 of 8 mussels show average valve position over 30 min decreased by $20 \%$ compared to a 30 -min period ending $1 \mathrm{~h}$ prior to the measurement; in other words, every $30 \mathrm{~min}$ the average valve position of a mussel is compared with the average valve position of $1 \mathrm{~h}$ before. If this value is lower than $20 \%$ and the threshold is crossed by at least 4 mussels then an alarm is generated. The 'decreasing average' evaluation detects a reduction in mussel activity and is generally more sensitive than the 'closed' alarm.

- Alarm A: 4 of the 8 mussels show increased open-closeopen movement frequency over $10 \mathrm{~min}$ when compared to a $10 \mathrm{~min}$ period ending $1 \mathrm{~h}$ prior to the measurement. The minimum increase ratio of activity is set at 10 (ratio is [frequency now]/[frequency previous]), and one movement is recorded as activity if the valve position of the mussel has altered more than $30 \%$ in one direction between two subsequent measurements.

\section{Toxicity tests}

The seven xenobiotics (Table 2) used for the toxicity tests may potentially be contaminants of the Po River. They were selected to cover a range of chemicals belonging to several categories and classes (i.e. metals, pesticides, hydrocarbons, phenols) and having different ways to affect the organisms.

The $A$. woodiana specimens were tested with addition of the chemicals to the tank harbouring the BEWS (Fig. 3). A pump was used throughout the trial for water recirculation and homogenous distribution of the chemical in the tank (Fig. 3).
Water temperature, $\mathrm{pH}$ ( $\mathrm{pH}$ meter HI 9026 Hanna Instruments) and oxygen level (oximeter Oxi 330i WTW) were monitored during exposures. At least $48 \mathrm{~h}$ was allowed between testing of the different chemicals. Experiments were conducted from 09:00 to 16:00 when the probability of spontaneous closing due to circadian rhythm was lowest, as established by observations during the acclimation period.

In the first series of experiments, conducted in September and October 2011, the mussels were exposed for $30 \mathrm{~min}$ to the following nominal concentrations: chromium $(\mathrm{Cr})$ 0.01, 0.05, $0.5,2.5,5 \mathrm{mg} / \mathrm{L}$; arsenic (As) $0.05,0.1,0.5,1,2.5 \mathrm{mg} / \mathrm{L}$; sodium dodecyl sulphate (SDS) $0.25,0.5,5,25,50 \mathrm{mg} / \mathrm{L}$; phenol 0.1, 1, 10, 50, $100 \mathrm{mg} / \mathrm{L}$; oxadiazon $0.001,0.005,0.05,0.5,5 \mathrm{mg} / \mathrm{L}$; trichloroethylene $0.01,0.1,1,10,100 \mathrm{mg} / \mathrm{L}$; and crude oil $0.5,1$, $5,10,50 \mathrm{mg} / \mathrm{L}$. This comprised concentrations lower than, equal to, and higher than the concentrations allowable under Italian standards for water to be treated for human consumption (Table 2). The recovery time following exposure with a contaminant until exposure with another one was at least $48 \mathrm{~h}$ (the dates of tests are indicated in Table 3). Between exposures of increasing concentrations of the same contaminant the bivalves were re-equilibrated for at least $30 \mathrm{~min}$ with flowing Po River water, which entered in the lower part of the tank and exited in the upper part to avoid mechanical stress to the mussels. The time needed by A. woodiana for recovery after a chemical stress was evaluated through preliminary tests; moreover, during the experiments the return to a normal pattern of valve movements, previously registered in the absence of any manipulation, was checked prior to starting a new exposure.

In the second set of tests, conducted in January 2012, A. woodiana were exposed for $6 \mathrm{~h}$ to one of the concentrations previously tested, generally $100 \mathrm{x}$ higher than the maximum concentration allowed under Italian regulations: chromium $5 \mathrm{mg} / \mathrm{L}$, arsenic $2.5 \mathrm{mg} / \mathrm{L}$, sodium dodecyl sulphate $25 \mathrm{mg} / \mathrm{L}$,
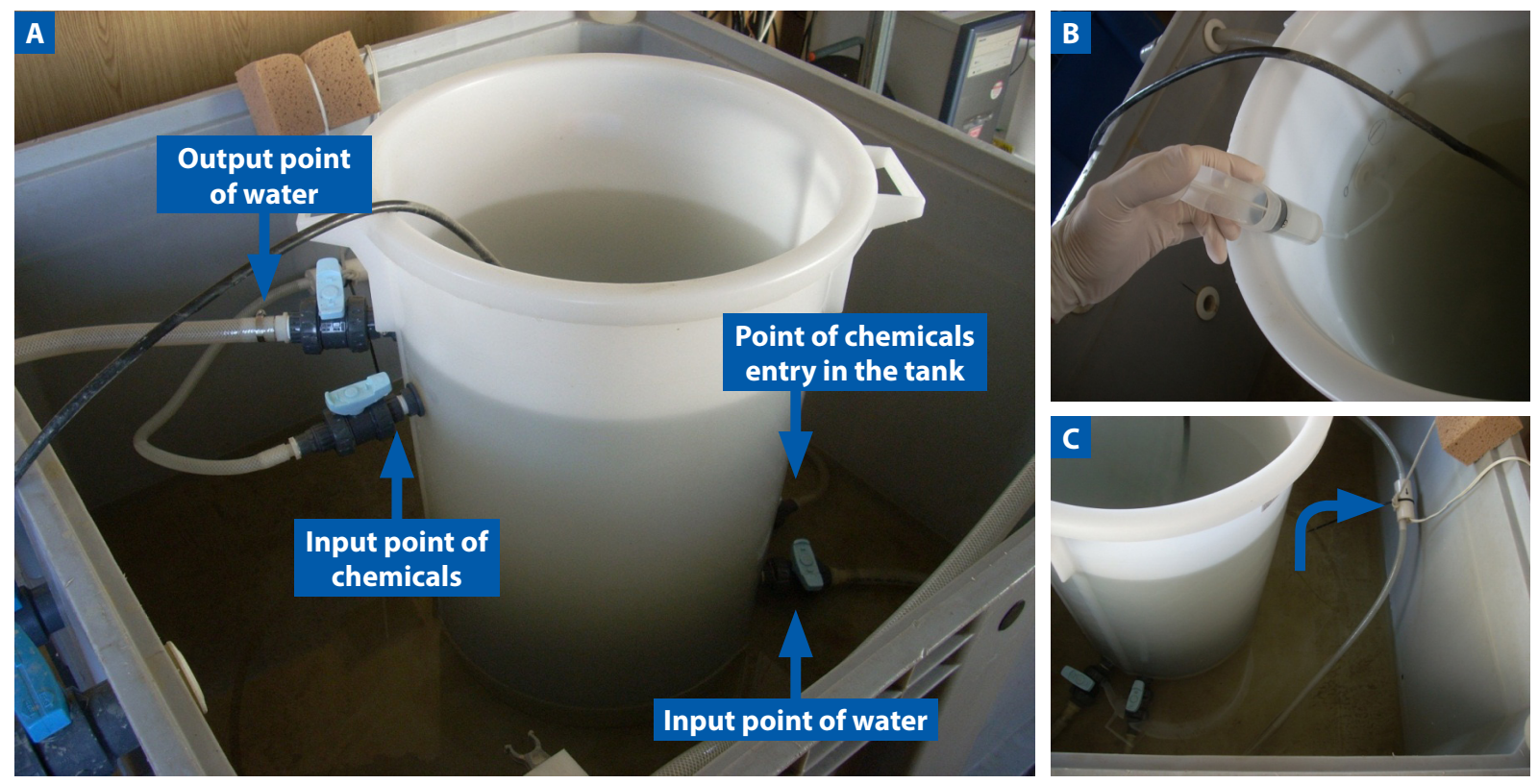

Figure 3

(a) Picture showing the polypropylene tank (60 L capacity) in which BEWS was placed and where the toxicity tests were conducted. The points of water and chemical entry and exit are indicated. (b) Addition of the chemical in the tank. (c) A pump (arrow) ensures the recirculation of water and chemicals within the tank. 
phenol $10 \mathrm{mg} / \mathrm{L}$, oxadiazon $0.5 \mathrm{mg} / \mathrm{L}$, trichloroethylene $1 \mathrm{mg} / \mathrm{L}$, and crude oil $10 \mathrm{mg} / \mathrm{L}$. At least $48 \mathrm{~h}$ was allowed between trials.

During exposures, temperature, oxygen level, and $\mathrm{pH}$ varied in the ranges reported in Table 3. Limited variations of these parameters were registered from the beginning to the end of each single experiment (Table 3). To ascertain the real concentrations of the xenobiotics in the tank during the two sets of tests, water samples were taken at the end of each exposure time and analysed following the USEPA methods (EPA $5030 \mathrm{~B}$ 1996; EPA 5021 A 2003; EPA 8015 D 2003; EPA 738 F 04/003; EPA 600 S 96/002; EPA 6020 A 2007; EPA 420.1 + EPA 420.2). The concentrations found in the tank were compared to the nominal concentrations using a paired t-test and no significant difference between them was found $(p>0.05)$.

\section{RESULTS}

No notable changes in the pattern of valve movements of $A$. woodiana were observed and consequently no alarms were recorded using the Mosselmonitor technology in response to As, Cr, crude oil, phenol, oxadiazon, trichloroethylene at any concentration tested (Table 3 ). Thus, the detection limits in the 30-min exposure test were not reached indicating that they were greater than the highest concentration used for each chemical, i.e., $2.5 \mathrm{mg} / \mathrm{L}$ for As, $5 \mathrm{mg} / \mathrm{L}$ for $\mathrm{Cr}, 50 \mathrm{mg} / \mathrm{L}$ for crude oil, 100 $\mathrm{mg} / \mathrm{L}$ for phenol, $5 \mathrm{mg} / \mathrm{L}$ for oxadiazon, and $100 \mathrm{mg} / \mathrm{L}$ for trichloroethylene. With prolonged exposure $(6 \mathrm{~h})$ sensitivity was at levels above $2.5 \mathrm{mg} / \mathrm{L}$ for As, $5 \mathrm{mg} / \mathrm{L}$ for $\mathrm{Cr}, 10 \mathrm{mg} / \mathrm{L}$ for crude oil, $10 \mathrm{mg} / \mathrm{L}$ for phenol, $0.5 \mathrm{mg} / \mathrm{L}$ for oxadiazon and $1 \mathrm{mg} / \mathrm{L}$ for trichloroethylene (Table 3).

Treatment with the surfactant SDS affected the normal pattern of behaviour of $A$. woodiana at 25 and $50 \mathrm{mg} / \mathrm{L}$, while at lower concentrations no reaction was discernible or strong enough to elicit an alarm. At the concentration of $50 \mathrm{mg} / \mathrm{L}$ SDS, Alarm C was generated immediately after $30 \mathrm{~min}$ of exposure (with 4 of 8 mussels closed) followed by Alarm D. The $6 \mathrm{~h}$ exposure to SDS $25 \mathrm{mg} / \mathrm{L}$ led to a decrease in the average valve opening distance (Alarm D from the end of the first hour through the second hour) and, subsequently, to the closure of most specimens (Alarm C, with 6 or 7 mussels closed, from the third hour to the end of the experiment).

\section{DISCUSSION}

In ecotoxicological studies, mussel closure response has often been proposed and applied as an aquatic biosensor to detect pollution (Sluyts et al., 1996; Borcherding, 2006). As reported in many publications (Doherty et al., 1987; Salánki and V.-Balogh, 1989; Doherty, 1990; Jørgensen, 1990; Borcherding, 1992; Bayne et al., 1993; Borcherding and Volpers, 1994; Ham and Peterson, 1994; Englund and Heino, 1996; Rodland et al., 2009), the presence of xenobiotics, changes in temperature or light intensity, or altered particle concentration in water can have an impact on shell opening, and for this reason valve movement behaviour of mussels is indicated as a BEWS. The aquatic environment is the final sink of an increasing number of contaminants, most of which cannot be continuously and efficiently detected by the traditional chemical techniques (Hantge, 1993; Borcherding, 2006). Thus, BEWS such as the Mosselmonitor used in this survey could represent a useful alternative method for the ongoing assessment of water quality. The first mussel monitors appeared in 1992 on the River Rhine in Germany (White et al., 2002). In Italy, the Metropolitan Water Supply of Turin recently used a Mosselmonitor, with Unio elongatulus as biosensor, on the Po River upstream of their water treatments plants (Badino et al., 2000).

The assessment of detection limits for chemicals and of the exposure time needed to elicit an alarm response is necessary in order to understand the sensitivity of a BEWS and its applicability to water monitoring. A crucial problem in ecotoxicology is the transferability of laboratory data to the field (Nusch, 1991). In the present study, in order to minimize the gap between laboratory toxicity tests and natural ecosystems, A. woodiana were subject to semi-field conditions before, during and after exposures.

To our knowledge, prior to this survey, there were no published data on Mosselmonitors employing A. woodiana or other species of this genus. There is a lack of information on the responses of mussel monitors to As, $\mathrm{Cr}$, and the pesticide oxadiazon; thus, results obtained with $A$. woodiana pertaining to these chemicals could not be compared with those obtained using other bivalve species. The threshold value of Mosselmonitors with Unio and/or Dreissena reported in literature is $0.005 \mathrm{mg} / \mathrm{L}$ for mercury and ranges from 0.005 to $1 \mathrm{mg} / \mathrm{L}$ for cadmium $\left(\mathrm{CdCl}_{2}\right)$ and from 0.25 to $0.5 \mathrm{mg} / \mathrm{L}$ for lead $\left(\mathrm{PbCl}_{2}\right.$ ) (Slooff et al., 1983; Faust, 1995; Badino et al., 2002). These levels are generally higher than the limits allowed under Italian regulations in water to be treated for human consumption (i.e. $0.001 \mathrm{mg} / \mathrm{L}$ for $\mathrm{Hg}, 0.005$ $\mathrm{mg} / \mathrm{L}$ for $\mathrm{Cd}, 0.05 \mathrm{mg} / \mathrm{L}$ for $\mathrm{Pb}$ ). In line with these data on metals, A. woodiana did not react to As at $25 \mathrm{x}$ or $\mathrm{Cr}$ at $100 \mathrm{x}$ the levels allowed under Italian limits.

With regard to SDS, Badino et al. (2002) reported that the Mosselmonitor using Unio pictorum generated an Alarm C when exposed for $24 \mathrm{~h}$ to a nominal concentration of $0.2 \mathrm{mg} / \mathrm{L}$, a value markedly lower than those found in this survey $(50 \mathrm{mg} / \mathrm{L}$ in the $30 \mathrm{~min}$ test and $25 \mathrm{mg} / \mathrm{L}$ in the $6 \mathrm{~h}$ test). For phenol and trichloroethylene, $A$. woodiana showed lower sensitivity when compared to the zebra mussel, Dreissena polymorpha, which responded to phenol at $14 \mathrm{mg} / \mathrm{L}$ and to trichloroethylene at concentrations ranging from 8 to $50 \mathrm{mg} / \mathrm{L}$ (Slooff et al., 1983; Matthias and Rompp, 1994; De Zwart et al., 1995). The detection limit of Mosselmonitor for dispersed oil has been reported only for the marine mussel Mytilus edulis and was at $6 \mathrm{mg} / \mathrm{L}$ (Kramer et al., 1989). We found no alarm signal at levels of $50 \mathrm{mg} / \mathrm{L}$ crude oil. Compared to other species used in Mosselmonitor, $A$. woodiana appeared to be less sensitive. However, as pointed out by Borcherding and Jantz (1997), detection limits must be compared cautiously, since, in addition to test species and the assessed endpoint, experimental protocol and duration of exposure as well as other test conditions can affect the results.

A major requirement of a BEWS is to detect the occurrence of a toxic substance in the environment within a period of minutes to 1 hour (Kramer and Botterweg 1991; Baldwin and Kramer 1994). Based on the definition by Schmitz et al. (1992), an alarm must be triggered within $30 \mathrm{~min}$ of the addition of a contaminant. Anodonta woodiana demonstrated no response to six of the seven chemicals tested within this time frame, nor within an exposure of $6 \mathrm{~h}$. The detection limits showed by $A$. woodiana for the seven xenobiotics assessed are much higher than the concentrations allowable under Italian legislation (see Table 2) as well as those normally found in Po River near Ferrara (see Table 1). Slooff et al. (1983) suggested that if the detection limits of xenobiotics by mussels are much higher than the concentrations found in the environment, it will decrease their value for biological monitoring. We experienced this situation with the Mosselmonitor using A. woodiana at this site. Only in highly contaminated sites or following dramatic pollution events would the tested chemicals reach concentrations sufficient to elicit a response. 
TABLE 3

Responses of Anodonta woodiana Mosselmonitor and mean \pm standard deviation (SD) of the physicochemical parameters of the Po water in the test tank during the exposures. Average and SD of 4 values (at 0, 10, 20, $30 \mathrm{~min}$ of exposure) for $30 \mathrm{~min}$ test and average \pm SD of 7 values (at $0,1,2,3,4,5,6,7 \mathrm{~h}$ of exposure) for $6 \mathrm{~h}$ test are reported.

\begin{tabular}{|c|c|c|c|c|c|}
\hline Test (30 min) & Response of Mosselmonitor & Date & $\mathrm{T}\left({ }^{\circ} \mathrm{C}\right)$ & $\mathrm{O}_{2}(\mathrm{mg} / \mathrm{L})$ & pH \\
\hline Arsenic $0.05 \mathrm{mg} / \mathrm{L}$ & $\mathrm{N}$ & $14 / 09 / 11$ & $23.5 \pm 0.1$ & $10.1 \pm 0.1$ & $7.31 \pm 0.03$ \\
\hline Arsenic $0.1 \mathrm{mg} / \mathrm{L}$ & $\mathrm{N}$ & & $23.7 \pm 0.1$ & $10.0 \pm 0.1$ & $7.36 \pm 0.03$ \\
\hline Arsenic $0.5 \mathrm{mg} / \mathrm{L}$ & $\mathrm{N}$ & & $23.7 \pm 0.1$ & $10.0 \pm 0.2$ & $7.32 \pm 0.06$ \\
\hline Arsenic $1 \mathrm{mg} / \mathrm{L}$ & $\mathrm{N}$ & & $23.9 \pm 0.1$ & $9.8 \pm 0.1$ & $7.29 \pm 0.05$ \\
\hline Arsenic $2.5 \mathrm{mg} / \mathrm{L}$ & $\mathrm{N}$ & & $23.9 \pm 0.1$ & $9.9 \pm 0.2$ & $7.27 \pm 0.09$ \\
\hline Chromium $0.01 \mathrm{mg} / \mathrm{L}$ & $\mathrm{N}$ & $17 / 09 / 11$ & $23.4 \pm 0.2$ & $9.8 \pm 0.2$ & $7.25 \pm 0.05$ \\
\hline Chromium $0.05 \mathrm{mg} / \mathrm{L}$ & $\mathrm{N}$ & & $23.5 \pm 0.2$ & $9.7 \pm 0.2$ & $7.20 \pm 0.04$ \\
\hline Chromium $0.5 \mathrm{mg} / \mathrm{L}$ & $\mathrm{N}$ & & $23.6 \pm 0.1$ & $9.9 \pm 0.1$ & $7.24 \pm 0.02$ \\
\hline Chromium $2.5 \mathrm{mg} / \mathrm{L}$ & $\mathrm{N}$ & & $23.6 \pm 0.1$ & $9.6 \pm 0.1$ & $7.23 \pm 0.03$ \\
\hline Chromium $5 \mathrm{mg} / \mathrm{L}$ & $\mathrm{N}$ & & $23.9 \pm 0.1$ & $9.5 \pm 0.1$ & $7.26 \pm 0.05$ \\
\hline Crude oil $0.5 \mathrm{mg} / \mathrm{L}$ & $\mathrm{N}$ & $07 / 10 / 11$ & $19.6 \pm 0.1$ & $10.2 \pm 0.1$ & $7.73 \pm 0.10$ \\
\hline Crude oil $1 \mathrm{mg} / \mathrm{L}$ & $\mathrm{N}$ & & $19.6 \pm 0.0$ & $10.3 \pm 0.1$ & $7.78 \pm 0.13$ \\
\hline Crude oil $5 \mathrm{mg} / \mathrm{L}$ & $\mathrm{N}$ & & $19.6 \pm 0.1$ & $10.3 \pm 0.2$ & $7.78 \pm 0.05$ \\
\hline Crude oil 10 mg/L & $\mathrm{N}$ & & $19.5 \pm 0.1$ & $10.1 \pm 0.1$ & $7.70 \pm 0.08$ \\
\hline Crude oil 50 mg/L & $\mathrm{N}$ & & $19.6 \pm 0.1$ & $10.2 \pm 0.1$ & $7.65 \pm 0.06$ \\
\hline Oxadiazon $0.001 \mathrm{mg} / \mathrm{L}$ & $\mathrm{N}$ & $30 / 09 / 11$ & $20.0 \pm 0.1$ & $10.9 \pm 0.1$ & $7.32 \pm 0.05$ \\
\hline Oxadiazon $0.005 \mathrm{mg} / \mathrm{L}$ & $\mathrm{N}$ & & $20.2 \pm 0.1$ & $10.7 \pm 0.1$ & $7.36 \pm 0.09$ \\
\hline Oxadiazon $0.05 \mathrm{mg} / \mathrm{L}$ & $\mathrm{N}$ & & $20.2 \pm 0.1$ & $10.7 \pm 0.1$ & $7.34 \pm 0.05$ \\
\hline Oxadiazon $0.5 \mathrm{mg} / \mathrm{L}$ & $\mathrm{N}$ & & $20.2 \pm 0.1$ & $10.7 \pm 0.1$ & $7.38 \pm 0.04$ \\
\hline Oxadiazon $5 \mathrm{mg} / \mathrm{L}$ & $\mathrm{N}$ & & $20.2 \pm 0.1$ & $10.8 \pm 0.1$ & $7.35 \pm 0.05$ \\
\hline Phenol $0.1 \mathrm{mg} / \mathrm{L}$ & $\mathrm{N}$ & $26 / 09 / 11$ & $19.9 \pm 0.1$ & $10.8 \pm 0.2$ & $7.15 \pm 0.04$ \\
\hline Phenol $1 \mathrm{mg} / \mathrm{L}$ & $\mathrm{N}$ & & $20.0 \pm 0.1$ & $10.6 \pm 0.1$ & $7.20 \pm 0.02$ \\
\hline Phenol 10 mg/L & $\mathrm{N}$ & & $20.1 \pm 0.1$ & $10.6 \pm 0.1$ & $7.19 \pm 0.02$ \\
\hline Phenol 50 mg/L & $\mathrm{N}$ & & $20.2 \pm 0.1$ & $10.5 \pm 0.2$ & $7.21 \pm 0.05$ \\
\hline Phenol $100 \mathrm{mg} / \mathrm{L}$ & $\mathrm{N}$ & & $20.3 \pm 0.1$ & $10.5 \pm 0.3$ & $7.26 \pm 0.04$ \\
\hline Sodium dodecyl sulphate $0.25 \mathrm{mg} / \mathrm{L}$ & $\mathrm{N}$ & $20 / 09 / 11$ & $22.0 \pm 0.1$ & $9.8 \pm 0.2$ & $7.41 \pm 0.06$ \\
\hline Sodium dodecyl sulphate $0.5 \mathrm{mg} / \mathrm{L}$ & $\mathrm{N}$ & & $22.0 \pm 0.1$ & $9.8 \pm 0.2$ & $7.45 \pm 0.04$ \\
\hline Sodium dodecyl sulphate $5 \mathrm{mg} / \mathrm{L}$ & $\mathrm{N}$ & & $22.1 \pm 0.2$ & $9.6 \pm 0.1$ & $7.42 \pm 0.04$ \\
\hline Sodium dodecyl sulphate $25 \mathrm{mg} / \mathrm{L}$ & $\mathrm{N}$ & & $21.4 \pm 0.1$ & $9.7 \pm 0.2$ & $7.43 \pm 0.04$ \\
\hline Sodium dodecyl sulphate $50 \mathrm{mg} / \mathrm{L}$ & $\mathrm{CD}$ & & $21.4 \pm 0.2$ & $9.7 \pm 0.1$ & $7.43 \pm 0.02$ \\
\hline Trichloroethylene $0.01 \mathrm{mg} / \mathrm{L}$ & $\mathrm{N}$ & $04 / 10 / 11$ & $19.7 \pm 0.1$ & $10.5 \pm 0.1$ & $7.49 \pm 0.07$ \\
\hline Trichloroethylene $0.1 \mathrm{mg} / \mathrm{L}$ & $\mathrm{N}$ & & $19.9 \pm 0.1$ & $10.5 \pm 0.0$ & $7.55 \pm 0.04$ \\
\hline Trichloroethylene $1 \mathrm{mg} / \mathrm{L}$ & $\mathrm{N}$ & & $19.9 \pm 0.2$ & $10.5 \pm 0.1$ & $7.54 \pm 0.03$ \\
\hline Trichloroethylene $10 \mathrm{mg} / \mathrm{L}$ & $\mathrm{N}$ & & $20.2 \pm 0.1$ & $10.4 \pm 0.0$ & $7.53 \pm 0.03$ \\
\hline Trichloroethylene $100 \mathrm{mg} / \mathrm{L}$ & $\mathrm{N}$ & & $20.1 \pm 0.2$ & $10.5 \pm 0.1$ & $7.52 \pm 0.06$ \\
\hline Test (6 h) & Response of Mosselmonitor & Date & $\mathbf{T}^{\circ} \mathrm{C}$ & $\mathrm{O}_{2}(\mathrm{mg} / \mathrm{L})$ & pH \\
\hline Arsenic $2.5 \mathrm{mg} / \mathrm{L}$ & $\mathrm{N}$ & $23 / 01 / 12$ & $8.4 \pm 0.6$ & $10.8 \pm 0.4$ & $6.82 \pm 0.25$ \\
\hline Chromium 5 mg/L & $\mathrm{N}$ & $10 / 01 / 12$ & $9.7 \pm 0.9$ & $10.3 \pm 0.3$ & $6.89 \pm 0.29$ \\
\hline Crude oil 10 mg/L & $\mathrm{N}$ & $30 / 01 / 12$ & $7.2 \pm 0.3$ & $11.2 \pm 0.7$ & $7.81 \pm 0.23$ \\
\hline Oxadiazon $0.5 \mathrm{mg} / \mathrm{L}$ & $\mathrm{N}$ & $13 / 01 / 12$ & $7.5 \pm 0.3$ & $10.4 \pm 0.2$ & $7.07 \pm 0.13$ \\
\hline Phenol 10 mg/L & $\mathrm{N}$ & $19 / 01 / 12$ & $8.0 \pm 0.3$ & $10.4 \pm 0.1$ & $7.09 \pm 0.03$ \\
\hline Sodium dodecyl sulphate $25 \mathrm{mg} / \mathrm{L}$ & DC & $26 / 01 / 12$ & $8.5 \pm 0.5$ & $10.6 \pm 0.1$ & $7.32 \pm 0.05$ \\
\hline Trichloroethylene $1 \mathrm{mg} / \mathrm{L}$ & $\mathrm{N}$ & $16 / 01 / 12$ & $7.0 \pm 0.1$ & $10.1 \pm 0.5$ & $7.28 \pm 0.50$ \\
\hline
\end{tabular}

$N=$ No alarm; $C=$ Closure alarm D = Decreasing average alarm 
The almost complete absence of alarm responses observed during the tests could depend on one or more of the following factors:

- The sensitivity and experimental conditions of $A$. woodiana. The selection of an appropriate test organisms is fundamental and varies depending on the water body being evaluated (Bae and Park, 2014). In addition, the experimental constraint associated with valve fixation could have affected the response and sensitivity of this species. Tran and collaborators (2003) documented that the shell movements of Corbicula fluminea differ between freely moving mussels and animals with one valve glued. They suggested that the mechanical disturbance due to valve fixing can produce a state of constant stress and consequently bias the response to the contaminants.

- The sensitivity of the system, i.e., the alarm thresholds used. The adjustment of the alarm generation criteria could highly modify the informativeness of BEWS and requires a lot of experience (Sluyts et al. 1996). Sluyts et al. (1996) compared the responses of Dreissena to copper exposures using the existing static thresholds of the Mosselmonitor with the results obtained with a dynamic alarm system developed ad hoc. The effects of copper on mussels were only detected at $80 \mu \mathrm{g} / \mathrm{L}$ with static alarm functions, but at lower concentrations (20 and $40 \mu \mathrm{g} / \mathrm{L}$ $\mathrm{Cu}$ ) with the dynamic alarm system, which was thus found to be more sensitive (Sluyts et al., 1996).

- The use of the same mussels for a whole series of tests. Although after each test the mussels returned to the typical movement patterns registered in the absence of stress, the chemical exposures could have affected the mussels' response to subsequent tests. With regard to metals, it was shown that the dosage experiments cannot be repeated on the same set of Dreissena due to adaptation effects (Kraak, 1992).

Over the past decades, biomonitoring systems, including Mosselmonitor, used to detect harmful chemicals in water bodies have measured the behavioural response of a single species. More recently, the newly proposed BEWS rely on different organisms that exhibit various levels of sensitivity and reaction times to the contaminants (Maradona et al., 2012; Bae and Park, 2014). Multispecies monitors provide more reliable results and can minimize the risks of false positives or false negatives (Maradona et al., 2012; Bae and Park, 2014). As underlined in the recent review by Bae and Park (2014), the worldwide use of BEWS for surveillance of natural aquatic ecosystems, drinking water, and wastewater effluents has many advantages but also poses the difficulty of analysing and interpreting large amounts of data. Further research and effort are required to improve the BEWS techniques and, in this regard, field studies on BEWS function and performance are pivotal (Madrid and Zayas, 2007).

\section{CONCLUSION}

The use of this BEWS employing freshwater mussels complies with the requirements for a good biomonitoring system (i.e. ease of use, low maintenance cost, resistance of biosensors to handling and chemical stress). The results of the present study highlight the need to establish the sensitivity of the sentinel species, in order to understand the usefulness and applicability of the BEWS in a specific context, such as the collection of drinking water from highly impacted rivers. In the situation herein evaluated, the utility of this BEWS with $A$. woodiana appears limited; thus, further tests should be carried out, using a more sensitive species, changing the mussels after each exposure and/or modifying the alarm thresholds of the instrument. Considerable experience and collection of data are mandatory for fruitful and reliable use of this BEWS.

\section{ACKNOWLEDGMENTS}

We thank Eng. Francesco Maffini and Mr Massimo Mari of HERA Ferrara for their assistance and Dr Luigi Trentini of the Environmental Protection Agency of Ferrara (ARPA) for kindly providing chemical data. We are grateful to Dr Edoardo Turolla of the University of Ferrara for technical help, to The Lucidus Consultancy for English correction of the manuscript and to the anonymous referees for helpful suggestions.

\section{REFERENCES}

BADINO G, PEDON E, SAINI M, MEUCCI L and GIACOSA D (2000) Rilevazione in tempo reale della qualità dell'acqua superficiale mediante Unio elongatulus come biosensore autoctono: ricerche e applicazione come sistema di preallarme. In: Proceedings of the National Convention on Ecotoxicology, July 2000, Turin, Italy.

BADINO G, MEUCCI L and GIACOSA D (2002) Il monitoraggio on line della qualità dell'acqua del fiume Po. AutMoNet 2002 Automation in Water Quality Monitoring, 21-22 May 2002, Vienna.

BAE M-J and PARK Y-S (2014) Biological early warning system based on the responses of aquatic organisms to disturbances: a review. Sci. Total Environ. 466-467 635-649. https://doi.org/10.1016/j. scitotenv.2013.07.075

BALDWIN LG and KRAMER KJM (1994) Biological early warning systems (BEWS). In: Kramer KJM (ed.) Biomonitoring of Coastal Waters and estuaries. CRC Press, Boca Raton.

BAYNE BL, IGLESIAS JIP, HAWKINS AJS, NAVARRO E, HERAL M and DESLOUS-PAOLI JM (1993) Feeding behaviour of the mussel, Mytilus edulis: responses to variations in quantity and organic content of the seston. J. Mar. Biol. Assoc. UK 73 813-829. https://doi. org/10.1017/S0025315400034743

BORCHERDING J (1992) Another early warning system for the detection of toxic discharges in the aquatic environment based on the valve movements of the freshwater mussel Dreissena polymorpha. In: Neumann D and Jenner HA (ed.) Limnologie Aktuell - Vol. 4 - the Zebra Mussel Dreissena polymorpha - Ecology, Biological Monitoring and First Applications in Water Quality Management. Gustav Fischer Verlag, Stuttgart.

BORCHERDING J (2006) Ten years of practical experience with the Dreissena-Monitor, a biological early warning system for continuous water quality monitoring. Hydrobiologia 556 417-426. https://doi. org/10.1007/s10750-005-1203-4

BORCHERDING J and JANTZ B (1997) Valve movement response of the mussel Dreissena polymorpha - the influence of $\mathrm{pH}$ and turbidity on the acute toxicity of pentachlorophenol under laboratory and field conditions. Ecotoxicology 6 153-165. https://doi. org/10.1023/A:1018666525205

BORCHERDING J and VOLPERS M (1994) The 'Dreissena-Monitor' first results on the application of this biological early warning system in the continuous monitoring of water quality. Water Sci. Technol. 29 199-201.

DE ZWART D, KRAMER KJM and JENNER HA (1995) Practical experiences with the biological early warning system "Mosselmonitor". Environ. Toxicol. Water 10 237-247. https://doi. org/10.1002/tox.2530100403

DOHERTY FG (1990) The Asiatic clam Corbicula spp. as a biological monitor in freshwater environments. Environ. Monit. Assess. 15 501-507. https://doi.org/10.1007/BF00398912 
DOHERTY FG, CHERRY DS and CAIRNS J (1987) Valve closure responses of the Asiatic clam Corbicula fluminea exposed to cadmium and zinc. Hydrobiologia 153 159-167. https://doi. org/10.1007/BF00006647

ENGLUND VPM and HEINO MP (1996) The freshwater mussel (Anodonta anatina) in monitoring of 2,4,6-trichlorophenol: behaviour and environmental variation considered. Chemosphere 32 391-403. https://doi.org/10.1016/0045-6535(95)00333-9

FABBRI R and LANDI L (1999) Nuove segnalazioni di molluschi, crostacei e pesci esotici in Emilia-Romagna e prima segnalazioni di Corbicula fluminea (O. F. Müller, 1774) in Italia (Mollusca Bivalvia, Crustacea Decapoda, Osteichthyes Cypriniformes). Quad. Stu. Not. Stor. Nat. Romagna 12 9-20.

FAUST J (1995) Ökotoxikologische untersuchungen mit dem dreissenamonitor unter besonderer berücksichtigung des einflusses von schwebstoffen auf die toxizität von 2-chlor-4-nitro-anilin, cadmium und pentachlorphenol. Diplomarbeit Universität zu Köln.

GIARI L, DEZFULI BS, LANZONI M and CASTALDELLI G (2012) The impact of an oil spill on organs of bream Abramis brama in the Po River. Ecotox. Environ. Saf. 77 18-27. https://doi.org/10.1016/j. ecoenv.2011.10.014

HAM KD and PETERSON MJ (1994) Effect of fluctuating low level chlorine concentrations on valve-movement behavior of the Asiatic clam (Corbicula fluminea). Environ. Toxicol. Chem. 13 493-498. https://doi.org/10.1002/etc.5620130319

HANTGE E (1993) Wie sauber ist der Rhein? Bericht uber die Wasserbeschaffenheit des Rheins in Rheinland-Pfalz. In: Ministerium fur Umwelt Rheinland-Pfalz (ed.) Die Biozo-nose des Rheins im Wandel - Lachs 2000? Advanced Biology Verlagsgesellschaft, Petersberg.

JØRGENSEN CB (1990) Bivalve Filter Feeding: Hydrodynamics, Bioenergetics, Physiology and Ecology. Olsen \& Olsen, Fredensborg.

KRAAK MH (1992) Ecotoxicity of metals to the freshwater mussel Dreissena polymorpha. PhD thesis, University of Amsterdam, Amsterdam, The Netherlands.

KRAMER KJM and BOTTERWEG J (1991) Aquatic biological early warning systems: an overview. In: Jeffrey DW and Madden B (eds) Bioindicators and Environmental Management. Academic Press, London. https://doi.org/10.1007/BF00027811

KRAMER KJM and FOEKEMA EM (2001) The 'Musselmonitor' as biological early warning system: the first decade. In: Butterworth FM, Gunatilaka A and Gonsebatt ME (eds) Biomonitors and Biomarkers as Indicators of Environmental Change. Vol. 2. Kluwer Academic Publishers, New York.

KRAMER KJM, JENNER HA and DE ZWART D (1989) The valve movement response of mussels: a tool in biological monitoring. Hydrobiologia 188 433-443.

KWAN KHM, CHAN HM and DE LAFONTAINE Y (2003) Metal contamination in zebra mussels (Dreissena polymorpha) along the St. Lawrence river. Environ. Monit. Assess. 88 193-219. https://doi. org/10.1023/A:1025517007605

LODDE A, PALMERINI E, SALA L and CASTAGNOLO L (2005) Anodonta woodiana (Lea, 1834) (Mollusca: Bivalvia: Unionidae), a non-indigenous species wide-spread in Italy: comparison of the biological cycle in native countries (Far East) and in Italy (Modena canals). IV International Congress of the European Malacological Societies, 10-14 October 2005, Naples (Italy). Notiziario S.I.M. 2370.

MADRID Y and ZAYAS ZP (2007) Water sampling: traditional methods and new approaches in water sampling strategy. Trac-Trend Anal. Chem. 26 293-299. https://doi.org/10.1016/j.trac.2007.01.002
MARADONA A, MARSHALL G, MEHRVAR M, PUSHCHAK R, LAURSEN AE, MCCARTHY LH, BOSTAN V and GILBRID KA (2012) Utilization of multiple organisms in a proposed early-warning biomonitoring system for real-time detection of contaminants: preliminary results and modeling. J. Hazardous Mater. 219- 220 95-102. https://doi.org/10.1016/j.jhazmat.2012.03.064

MATTHIAS U and ROMPP S (1994) Erprobung des dreissena-monitors, eines neuen biotestsystems mit der zebramuschel (Dreissena polymorpha), in der Rhein-Gutemeßstation Karlsruhe. Acta Hydroch. Hydrob. 22 161-165. https://doi.org/10.1002/aheh.19940220402

MOSSELMONITOR (2005) An early warning system for online monitoring. URL: http://www.Mosselmonitor.nl/01_engels/01_ starteng.htm (Accessed May 2011).

NUSCH EA (1991) Okologische testverfahren - anforderungsprofile in abhangigkeit vom anwendungszweck. Z. Umweltchem. Okotoxikol. 3 12-15. https://doi.org/10.1007/BF02940505

RODLAND DL, SCHONE BR, BAIER S, ZHANG Z, DREYER W and PAGE NA (2009) Changes in gape frequency, siphon activity and thermal response in the freshwater bivalves Anodonta cygnea and Margaritifera falcata. J. Mollus. Stud. 75 51-57. https://doi. org/10.1093/mollus/eyn038

SALAHSHUR S, BAKHTIARI AR and KOCHANIAN P (2012) Use of Solen brevis as a biomonitor for $\mathrm{Cd}, \mathrm{Pb}$ and $\mathrm{Zn}$ on the intertidal zones of Bushehr-Persian Gulf, Iran. Bull. Environ. Contam. Toxicol. 88 951955. https://doi.org/10.1007/s00128-012-0599-6

SALÁNKI J and V-BALOGH K (1989) Physiological background for using freshwater mussels in monitoring copper and lead pollution. Hydrobiologia 188/189 445-454. https://doi.org/10.1007/BF00027812

SCHMITZ P, IRMER U and KREBS F (1992) Einsatz kontinuierlicher Biotestsysteme zur Uberwachung des Rheins. In: Steinhauser KG and Hansen P-D (eds) Biologische Testverfahren. Beitrage zu den BiotestStatusseminaren 1989 und 1992. Gustav Fischer Verlag, Stuttgart.

SLOOFF W, DE ZWART D and MARQUENIE JM (1983) Detection limits of a biological monitoring system for chemical water pollution based on mussel activity. B. Environ. Contam. Toxicol. 30 400-405. https://doi.org/10.1007/BF01610151

SLUYTS H, VAN HOOF F, CORNET A and PAULUSSEN J (1996) A dynamic new alarm system for use in biological early warning systems. Environ. Toxicol. Chem. 15 1317-1323. https://doi. org/10.1002/etc.5620150809

STOREY MV, VAN DER GAAG B and BURNS BP (2011) Advances in on-line drinking water quality monitoring and early warning systems. Water Res. 45 741-747. https://doi.org/10.1016/j. watres.2010.08.049

TRAN D, CIRET P, CIUTAT A, DURRIEU G and MASSABUAU J-C (2003) Estimation of potential and limits of bivalve closure response to detect contaminants: application to cadmium. Environ. Toxicol. Chem. 22 914-920. https://doi.org/10.1002/etc.5620220432

WATTERS GT (1997) A synthesis and review of the expanding range of the Asian freshwater mussel Anodonta woodiana (Bivalvia: Unionidae). Veliger 40 152-156.

WAYKAR B and SHINDE SM (2011) Assessment of the metal bioaccumulation in three species of freshwater bivalves. Bull. Environ. Contam. Toxicol. 87 267-271. https://doi.org/10.1007/ s00128-011-0354-4

WHITE B, GIBERT M and DEININGER R (2002) Biological monitors. In: Hargesheimer EE, Conio O and Popovicova J (eds.) Online Monitoring for Drinking Water Utilities. AWWA Research Foundation/CRS PROAQUA, Denver. 